\title{
The care-less manager: gender, care and new managerialism in higher
}

Education

\section{Bernie Grummell, Dympna Devine and Kathleen Lynch}

(Draft Article; Forthcoming in Gender and Education journal)

\section{Introduction: Commercialism and Neo-liberalism in Higher Education}

With the rise of neo-liberal politics, public services, including education, have become increasingly redefined as market commodities (Stevenson 1999, Bonal 2003, Angus 2004, Rutherford 2005). Higher education has been especially targeted for commercialisation, with a growing emphasis on turning universities into enterprises servicing the market (Slaughter and Leslie 2001, Giroux 2002). Under the influence of the GATS (General Agreement on Trade and Services) there is an ongoing movement to define education as a tradable service worldwide (Bok 2003, Lynch 2006). Defining education as a market commodity has also become increasingly normalised in international policy discourse. At European level, it is promoted through the Lisbon Strategy, the purpose of which is to make the EU a leading global economic power, by being 'the most dynamic and competitive economy' by 2010 . The OECD has also promoted a market model of education; their position is exemplified in their report on Higher Education in Ireland (2004), which claimed that the primary role of higher education was to develop a 'skilled work force for the economy'. The Irish government has endorsed the OECD mantra, promoting a market model, not only in higher education but at all levels of education and public policy (Sugrue 2004, Lynch and Moran 2006, Allen 2007). The move to the market shifted the focus of service delivery from one of democratic accountability in education to market accountability. This has profound gender implications, not least because of the 
implicit, and sometimes, explicit, definition of the citizen that is at the heart of marketised models of education.

\section{The Care-Less Manager}

While many feminist scholars have documented the impact of neo-liberal policies on women in higher education (Stanley 1997, Morley 1999, Blackmore 1999, 2002, Blackmore and Sachs 2000, Deem 2003, Deem and Ozga 2000, Ozga and Deem 2000) the ways in which the greedy institutions of the academy interfaces with the greedy institution of informal care for senior women needs greater attention (Currie et al. 2000). The fact that women do a disproportionate amount of the care within educational institutions (including higher education) is well known (Acker 1995, Blackmore and Sachs 2000, Morley 1999), what is less well known is how the private demands of caring interface with paid work demands at top management levels. This is especially problematic in a neo-liberal age when higher education managers are judged by simplified, measurable performance indicators.

While new managerialism gave the impression that it was gender neutral, allowing new opportunities for women through a meritocratic code, in reality it was not (Hearn 1999, Blackmore 2002). The highly individualised capitalist-inspired entrepreneurialism that is at the heart of the new academy (Slaughter and Leslie 2001) has allowed old masculinities to remake themselves and maintain hegemonic male advantage. Not only has the new capitalist academy provided global opportunities for mobile transnational masculinities as Connell (2000) suggests, it also imposes expectations of performativity that only a care-less worker can fully satisfy. As women are significantly less likely to be care-free than men, regardless of their age or 
status (Pettinger et al. 2006), their capabilities for satisfying performativity demands are lesser within the new managerial regime. This also holds true for women in higher education (Probert 2005). In higher education, especially at senior levels, 'the ideal worker continues to be seen as one with no interests or responsibilities outside of work'; this profoundly disadvantages women (Bailyn 2003: 141).

\section{The Study in Context}

The aim of this paper is to demonstrate how the market model of education has impacted on both the definition and practice of senior managerial appointments in the higher education sector in Ireland. In particular it examines the gendered impact of these changes in relation to care, as neo-liberal values of individualism and performativity dominate senior management cultures.

While neo-liberal values and new managerial policies have been relatively successfully contested in Irish education, especially at primary and second-level, this is not true of higher education. The ability of the primary and second-level sectors to constrain new managerial discourses and developments (as evidenced by their success in forestalling the introduction of league tables such as those in the UK) is related to the influence of a highly organised trade union movement in both sectors (with over $90 \%$ of teachers being union members in just three trade unions), and a strong tradition of partnership between teacher unions, managerial bodies, parents and the Department of Education and Science, a partnership which is enshrined in legislation (the Education Act, 1998). Within higher education, the legislative and organisational framework is very different. There are a wide range of competing actors (including a range of trade unions within each college, and each sector of higher education, and 
lower trade union membership, especially among academics). Moreover, legislation governing higher education sectors (University Act 1997 and Institutions of Technology Act 2006) gives executive powers to college presidents that do not apply at either primary or second-level. While there has been resistance, including strikes, media campaigns and public protests within higher education, these have not had the same impact as the trade unions in higher education sector do not have the same negotiation powers (they cannot close down primary schools and thereby prevent parents going to work), or the same tradition of trade union activism for a host of complex reasons, including the competitive individualism of academic life itself. (The differences between sectors in terms of the impact of new managerialism is analysed elsewhere, Lynch et al. 2006, Grummell et al. 2009)

This paper is based on the analysis of interview data from case studies of seven toplevel appointments (at the level of Vice Chancellor, President, Vice-President, Provost, Director) in the higher education sector in Ireland ${ }^{1}$. Three of the cases involved recently appointed male senior managers and an assessor from their selection board, while the other four cases involved recently appointed female senior managers and an assessor from their selection board (except in one casestudy where the senior appointee was the only person interviewed); 13 interviews in all. The institutions involved include three universities, two institutes of technology, one further education college and one other education body (although these details are generalised in this article to preserve the anonymity of respondents from this small educational field ${ }^{2}$ ). Similar case studies were also completed with senior managers at primary and second level education, and these are analysed elsewhere (Lynch et al. 2006, Grummell et al. 2009). 
The case studies investigated the entire appointments process, including the way in which the post was defined, how appointees were recruited, experience of the successful appointee of the senior post, and views of at least one assessor from each appointments board. It examined the cultural codes enshrined in senior appointments from the perspective of those who assess senior appointees in higher education (all of whom are or have been heads of higher education colleges), and current incumbents of senior posts. Given the small number of universities and higher education colleges in Ireland, the study gives a clear indication as to how senior appointees in Irish higher education are expected to perform their job.

\section{Neo-liberalism: The Rational Economic Actor Model of the Citizen Worker}

The commercialisation of education has its origins in neo-liberal politics, a central goal of which is reducing the cost to capital of state expenditure on public services (Harvey 2005). It is premised on the assumption that the market should displace the democratic State as the primary producer of cultural logic and value (Lynch 2006:34). Within the neo-liberal frame, the citizen is defined as a rational economic actor (REA), essentially a worker and consumer; an autonomous rational actor governed by competitive individualism. This emphasis on the creation of self-sufficient and market-oriented citizens builds on the long history of gendered liberal political thinking that underestimates the role of dependency and interdependency in human relations (Fraser and Gordon 1997, Sevenhuijssen 1998, Kittay 1999). The liberal tradition does not recognize fully the role that emotions play in our relationships and actions (including teaching and managing), and is largely indifference to the centrality of care and love relations in defining who we are (Nussbaum 2001, Noddings 2003). 
With the rise of neo-liberalism there has been an enhancement of the rational economic actor model of the citizen (Tronto 2001), and the result is the creation of an education system increasingly focused on priming workers to pursue their individual market interests (Masschelein and Simons 2002, Lynch, et al. 2007). Higher education has increasingly shifted from having a public service ethos to focusing on creating workers for a capitalist knowledge economy (Harkavy 2005). The person to be educated is defined in economic terms, as 'homo economicus', a market-based actor whose life and logics will be determined by their training and future economic status (Apple 2001, Giroux 2002). Thus, education becomes another service to be delivered on the market to those who can afford to buy it. The job of the educational manager is to follow the market directive, a directive which governs the norms of her or his own participation (Blackmore and Sachs 2000, Davies et al. 2006)). The rationalisation that is offered for moving to the market is that it provides people with choice and efficiency in a meritocratic manner, not only for the 'consumers' but also for the 'managers'. Yet, the evidence is overwhelming that only those 'consumers' with sufficient resources can make education choices within an unequal society Gewirtz et al. 1995, Lauder and Hughes 1999, Reay and Lucey 2003, Lyons et al. 2003) and the only senior managers who can succeed in the so-called meritocratic system within higher education are those who can devote themselves relentlessly to their occupational life (Bailyn 2003). Informal care and love relations are defined out of senior posts as the manager citizen is assumed to be a care commander (paying or getting others in some societally approved away) to do the care work, rather than a care foot soldier, a person who does the caring for others and the caring about (for further discussion of these issues see Tronto 1993, Lynch et al. 2009). 
Yet, through a growing body of feminist scholarship, there is acknowledgement that the public functions of life, including teaching and managing, could not take place without primary care work (Fineman 2004). Feminist scholarship has also enabled us to appreciate how care responsibilities have an enormous impact on how one leads and manages, not least because of the time constraints that primary care work in families imposes (Daly 2001, Folbre and Bittman 2004). And there is an appreciation that caring is an acutely gendered issue, as women remain the primary carers in society, regardless of their class, age, cultural background or employment status (Bailyn 2003, Reay et al. 2005, Williams 2004, Pettinger et al. 2006).

To understand the ways in which management and care work are interwoven, it is necessary to disaggregate the roles that women and men play in relation to care. This article investigates how care is not only a set of social practices but a strongly gendered one with deep moral connotations (O’Brien 2007).

\section{Denying Gender and the Moral Imperative to Care}

The case studies reveal profound differences between women's and men's narratives about care, and their engagement with their role as senior managers. The female interviewees were familiar with the language of caring and spoke at length and spontaneously about the impact of care responsibilities on their work lives. Male interviewees only attended to the subject in passing, if at all; it did not seem part of their mind map in their senior managerial roles. While women in the higher education sector could not ignore care work, especially in the private sphere, men could and did. The theme of care, children and time conflicts was not part of our conversations with 
men unless we specifically introduced the subject. This indifference to care issues is implicitly supported by the culture of the public sphere, where the language of care and personal life remains invisible in public and work life (Nussbaum 2001).

Over the last 30 years Ireland has passed a wide range of equality legislation, much of it underwriting the rights of women. Employment Equality Act (1998) and the Equal Status Act (2000) prohibit direct and indirect discrimination on gender and eight other grounds, including family and marital status, not only in employment but in the provision of services. Moreover, gender mainstreaming became a major goal of public policy from the mid-1990s and was enshrined as a core objective of Irish public policy, including education (McGauran 2004; O’Connor 2007a). The enactment of equality legislation and development of national equality proofing guidelines and other initatives, resulted in a general assumption that gender inequalities were resolved. Yet, the low representation of women in higher education at senior management level internationally (Deem and Ozga 2000, Lafferty and Fleming 2000, Knights and Richards 2003, Ducklin and Ozga 2007) is mirrored in Irish higher education. While the proportion of women at senior level has increased so too has their representation at the lowest grades ${ }^{3}$ (O’Connor 2007a, Lynch et al. 2006).

Ironically, the enactment of equality legislation has silenced the debate about gender, including gender inequalities in higher education. The Higher Education Equality Unit (which was funded by the Higher Education Authority, HEA) was closed down and incorporated into the HEA in the early 2000s; since 2004 the HEA have produced no statistics on the status of women in higher education. There has been a silencing of dissent about gender issues generally, including the issues of care and how it impacts 
on women and their employment (Barry 2008; Lynch and Lyons 2008; O’Brien 2008).

The assumption that gender 'was not an issue' was evident in the unproblematic gender profile of senior management presented by many of the male interviewees in this research. Male selection board assessors argued that gender was not relevant when it came to assessing candidates, as the selection process was 'gender blind at this stage...it's stating the obvious, the gender of applicants simply doesn't register on anyone’s radar anymore' (Male assessor at Saltees higher education institution ${ }^{4}$ ). Senior male assessors for top-level higher education posts referred to the regulatory power of equality legislation over all appointment and employment situations, including the requirement to have gender representation on selection boards, as defences against possibility of gender inequality.

Contradictions were evident in these statements, however, as interviewees acknowledged the low base from which female appointments to senior management ranks were emerging. Male interviewees cited increasing numbers of women appointed in their own institutions as evidence of the changing situation; but also admitted, when probed, that caring responsibilities for a young family did impact on application rates for senior management posts. 'I know there are a few people who didn't apply for the job because they had young families, and I'm talking about women now, yes you would be right on that one' (Male assessor for Achill higher education institution). This 'dissonance between the rhetoric of equality of opportunity and the practices of everyday social relations and organisational life' that Ducklin and Ozga (2007:642) describe is evident in the contradictory attitudes of 
these respondents. There was a denial of gender inequality on a structural or institutional level, but an acknowledgement of gender differences in levels of applications. Assessors interpreted and rationalised the differences between the two narratives in terms of the individual 'choices' of women in the colleges. They accepted that there was a moral imperative imposed on women to care but they did not question the cultural presumptions that women were 'natural carers' and that men were exempt from this obligation. Most male assessors were blind to the genderspecific impact of care work and did not recognise how the family and care status of women impacted on women's decision to apply for a senior management post in the first instance. However, the attribution of causality for the low representation of women in top management positions to the 'choices' of individual women, exonerated assessors and other male appointees from having responsibility for perpetuating the continued male dominance of senior appointments.

The female assessors and senior managers, on the other hand, noted gender-related improvements but were acutely aware of structural and cultural constraints on women's choices. One female assessor observed that the reason so few women were in senior posts at higher education was because the criteria were written in such a way that it assumed particular types and length of experience at management level; by definition these excluded women. 'By the mere fact that you are looking for management experience in terms of criteria...you may, in itself, be limiting your field...There are less women with that experience so you are, by definition, excluding them' (Female assessor for Tory higher education institution). The competitive nature of higher education recruitment clearly leaves women, especially those with children and/or care responsibilities for older relatives or dependents, at a disadvantage as they 
will often have taken maternity or care leave, and/or career breaks, thereby disrupting their career progression and previous management experience (Brooking et al. 2003, Grummell et al. 2009).

The language that the interviewees used about balancing childcare and work responsibilities was very significant; caring was always assumed to be a women’s ‘problem’. Taking a career break or job-sharing was defined as an appropriate moral choice for women; it was part of being a 'good mother'. No such moral imperative existed for fathers.

\section{Balancing Care Responsibilities and Career Dedication}

It is generally acknowledged that academic work is without boundaries especially under new managerial regimes. There is no clear end to the amount of work one can do or the time in which one can do it; moreover, hours spent at work are increasing (Barry et al. 2003). Academic institutions are 'greedy' in terms of the level of commitment, work productivity and emotional engagement that they expect of employees (Currie et al. 2000). Given the moral imperative on women to care, it is inevitable that the academy imposes a considerable demand on them as they try to balance the competing claims of two greedy institutions, paid work and home (Coser 1974, Franzway 2000). Just as there is no clear boundary as to how much work one can do in academic life, so there is no end to the amount of care that others may expect from their primary carers. It is not surprising therefore that women in academic life often delay having children or decide not to have them at all (Bailyn 2003, Acker and Dillabough 2007). 
The management of child bearing and caring becomes crucial to determining women's future career paths, including senior management possibilities. One female senior manager described her past experience of working in several universities, where she saw women taking temporary posts to accommodate their caring roles. This meant they did the lower status work of departments; work that was not then recognised and was of little career value (Gronn and Rawlings-Sanaei 2003)

My experiences of women who get PhDs and then immediately have a baby and then look for a job and then suddenly find that they can't get it or their husband has got themselves a job and then they are tied into that city...that is the death nail to a research career; temporary work, lecturing, all the hours that God sends at the low level courses that nobody else wants, massive amounts of grading, no time for research, any other time spent with the kids. It is absolutely lethal and [happens] much more with females than males (Female senior manager at Rathlin higher education institution).

Academic career structures increasingly demand single-minded dedication to one's profession. This career dedication also coincides with cultural expectations about management experience (Moreau et al. 2007). If a candidate took time out from work for childcare, this implied a lack of commitment to the profession.

I still do think there is that perception there that if somebody has taken a couple of years out or hasn't gone for promotion at a particular time for their own personal reasons that that does go against them. So they find it difficult having maybe not availed of an opportunity on one occasion to then get over that when in three to five years time they wish to now avail of the opportunity, because another bright spark has come up in the meantime, or 'why didn't you go the last time? Or are you fully committed to this?' I think there are still issues around that. (Female assessor at Tory higher education institution)

For assessors, this created the conundrum of having to judge similar candidates by the length of their management experience when appointing senior managers (Grummell et al. 2009). As this assessor pointed out, the invisibility of care in the neo-liberal world resulted in corresponding gaps in relevant work experience during this time. When appointments are judged purely on work experience (in this case, management 
experience), women who have taken time out for care responsibilities are automatically disadvantaged (Davis-Netzley 1998, Gronn and Rawlings-Sanaei 2003). They were judged to lack the kind of commitment that the greedy institution expected of them.

[If] there are two people in front of you and one of them has six years management experience and the other has only two, it is difficult to come back and say that the one with two is a superior candidate. So I don't think anyone is saying that the person with two years experience couldn't do the job, but you are in a competitive situation and it is going to be very difficult to say to the one with six 'well sorry'. (Female assessor at Tory higher education institution)

Female appointees also described how they feared that they would be disadvantaged if they took time out or availed of any childcare supports during work: 'I'm not sure that I would have taken advantage of it [job-sharing] because I would have been afraid that it might have negatively impacted on me, maybe I was just paranoid about it' (Female senior manager at Rathlin higher education institution). They felt that their childcare responsibilities had to remain invisible in their career; leading them to try to compete equally with those who had no caring responsibilities. These expectations surrounding career paths and the denigration of care and gender also intersected with a complex range of other cultural and structural factors, including self-confidence creating powerful disincentives for female applicants. A female senior manager described how many women were

...never-endingly felt that they weren't good enough. I don't know how we are going to get over the 'not good enough' in women...Men don't seem to think about whether they are right for the job... Women never-endingly say 'I couldn't do it, I'm not good enough, look at what he is doing, look at what she is doing' and they don't apply... (Female senior manager at Valentia higher education institution)

Given the moral imperative on women to care, she claimed that women had little choice about opting out of senior management. 
I think also an awful lot of women are simply determining that their work/life balance, and particularly their child rearing possibilities, would be absolutely constrained by being appointed to a more senior post. (Female senior manager at Valentia higher education institution)

Ironically, the lack of women in senior management posts had further consequences for women who became senior managers, disadvantaging them in the most valued aspect of academic work, research.

The biggest issue is that there are still so few women at a senior level that proportionately too much of our time is being taken on interview boards; it is actually quite a serious problem...this small number of women who are very good researchers are now finding their time available for research is being eroded by going onto interview boards, selection boards, committees of all kinds when trying to get gender representation. (Female assessor at Inismeain higher education institution)

The equality legislation, intended to promote women's participation in senior management, has had contradictory effects: it puts immense strains on current female senior managers to service boards, thereby deepening the cultural divide between men and women's experiences of academic life and senior management. This continued the vicious circle of women having less visibility (due to a lower research portfolio), while also being extra-visible for gender equality purposes (O’Connor 2007a).

\section{Senior Management and the Invisible Cost of Caring}

Not surprisingly, one of the most noticeable features of this research was the gendered nature of the care responsibilities of the senior managers at different education levels. Male and female senior managers in the primary and second level sectors tended to be married with several young children, reflecting its status as a relatively care-friendly profession. On the other hand, senior managers in the higher education sector were older and tended to have fewer children (most of whom were teenagers when they were appointed). This was particularly noticeable in the family situation of female 
senior managers in this research. Of the six women interviewed who were either recently appointed senior managers or assessors (who also held senior management posts themselves), three had no children. Of these three who had children (five children in all), all but one of these was an adult (over 18 years in most cases). Of the seven men in senior posts at this level, just one had no children (he was relatively young and had only been married a short while), two had young children (pre-primary and primary) while the others had adult children.

While this study was not designed to provide a statistically accurate profile of senior managers in Irish higher education, it would appear that women who attained senior positions were less likely than men to have children, and if they did have children they tended to be adults or nearing adulthood before the women were appointed. In contrast the male senior managers whom we interviewed were younger when appointed, and were more likely to have children, and to have younger children than women. This profile is similar to international studies (Hensel 1991, Acker and Dillabough 2007) and highlights the more general dilemmas faced by female senior managers in terms of having children (Hewlett 2002).

\section{Deciding to have or not have Children}

The women in this study described how their career choices impacted on their decision to have children. Two of the women stated that they did not have more children (they had one and two respectively) because of the difficulties of combining senior posts of responsibility with having children. In one case, it was the experience of coming back to work with a team of people who did not approve of a relatively senior person taking maternity leave that instigated this decision. The senior manager 
in question felt there was no recognition of her needs as a mother with a very young baby.

It broke my heart so that was the end and I determined, no more children I just couldn't cope with it, it was heartbreaking..... I didn't feel that I could tell them that I was breastfeeding and I needed a cup of tea or a glass of water or something. (Female senior manager at Valentia higher education institution)

Like other senior managers, she individualised her circumstances and defended her employers' behaviour rather than focus on deeply gendered cultural and structural constraints (Beck and Beck-Gernsheim 2002). She expressed an internalised sense of having inconvenienced her employer and colleagues, and was apologetic for her mothering responsibilities.

But they were very kind decent people, I'm not saying for a second, this wasn't bias or anything it's just that they had never faced this, they must have thought that they had got a mad woman, I mean I totally understand. (Female senior manager at Valentia higher education institution)

Another female senior manager also outlined how her decision not to have a second child was made to ensure that she got a permanent academic post. She believed that getting into a tenured track would have been impossible with pregnancy or a second young child: 'I mean it was a big influence in only having one, I never had another one...I made a conscious decision that I couldn’t get tenure and be pregnant and have a second child, it was just not going to happen.' (Female senior manager at Rathlin higher education institution)

The male managers defined care-related decisions, including pregnancy and jobsharing, as a woman's choice. They did not assign themselves a role in this process, and in that sense did not see it as an issue for men. The senior manager at Achill higher education institution explained that his wife took a one-year career break when 
their child was born. When the career break was not extended 'she resigned...she made a choice and in ways it was a hard choice, I mean...it's her only child...suddenly this little being was there and she made the right decision'. The possibility that he could take on a care role was not mentioned. Other male senior managers and assessors similarly assumed that childcare was women's work. While some mentioned the fact that the work of childcare was negotiated in their households, the end of these negotiations followed a fairly predictable gendered pattern, with women taking primary responsibility for managing and doing childcare. The male interviewees accepted that women would work part-time or take leave to do childcare. However, they did not name this as an option for themselves.

None of the male senior managers in higher education indicated that they played a major role in childcare in the past or at present. Both women and men believed that senior level posts in higher education were not designed in a way that accommodated caring or any other responsibilities.

The higher you go the reality is that the options are much starker. If you take jobs at my level, it would be well nigh impossible to job share in my job to have a two day or three day week situation in my job, extraordinarily difficult. You are lucky to get a five-day week. You know, so it is very difficult because at that level it tends not to be simply about whether you are working two or three days, the reality is the buck stops with you. So the mobile phone rings at 11 o'clock at night, so the jobs at a particular level they simply are very significant life choice issues in that you actually are taking on a whole range of responsibilities and commitments rather than a schedule of time. (Male Assessor at Saltees higher education institution)

The male senior appointees rarely mentioned care as a factor in their own career choices. Instead they described how they were able to concentrate their personal and professional lives to achieve their career ambitions. As the senior manager at Inismeain higher education institution outlined, he was 'single focused' on his work 
until his late 30s when he got married, so childcare was not an issue for him. Like other senior managers, this single-mindedness was enabled by the support of partners who were the primary care-givers; 'I’m lucky in that sense, I suppose, I'm well supported, I know [my daughter] is very well cared for [by my wife]' (Male senior manager at Achill higher education institution)

\section{Care Supports: Primary and Secondary Roles in Caring}

The crucial importance of having a supportive partner if one holds a senior management post was emphasised by the female senior managers more than men. It seemed that men assumed that they would have care supports if they held a senior post (especially if they had children), while women could not take it for granted. Female senior managers noted that having a supportive partner when managing at a senior level was of great importance (Hensel 1991). One of the female senior managers acknowledged that her 'care-less' status, in not having children and having a supportive partner, were crucial to her own ability to avail of promotional opportunities. Referring to her appointment, she described how.

We don't have kids so that made it a lot easier. You wouldn't maybe make a decision as quickly if you had a family to move around but also the consequences would have been quite phenomenal. So I just phoned my husband and said 'I'm going.' He was happy as well'. (Female senior manager at Tory higher education institution)

The senior manager at Valentia higher education institution described the tremendous support that her partner gives her and contended that most of the women she knew who were successfully combining childcare with senior management had supportive partners. 
They are doing it [senior management post] because, for whatever reason their male partners are in a position to more significantly contribute. My sister is a principal in a very large school, the first lay principal in a very large secondary school and her husband works around her needs. He is the one who drops and collects and that sort of thing. (Female senior manager at Valentia higher education institution)

Another female senior manager also mentioned the importance of her partner; 'I mean it is actually helpful for me to have a partner because I bounce things off him and he is supportive' (Female senior manager at Rathlin higher education institution). This interviewee was the only senior manager who had been a single parent. She contrasted her experience now with her partner to earlier in her life when she was parenting alone; 'I suppose there was a kind of loneliness about being female there. I was a single mother and I didn't find that very easy' (Female senior manager at Rathlin higher education institution). ${ }^{5}$

Most men saw their role as parents as a care facilitator, being a secondary rather than a primary carer. They mentioned moving house or changing work hours to facilitate the caring of children with a spouse, but their main career-related decisions were not influenced by care responsibilities.

I leave at six and my three year old grabs me for the night, and that's it, I play dollies (laugh)...I switch off at ten o'clock at night when she's gone to bed. If she wasn't there, I would be back here, I'd say three or four evenings a week, and it's probably a good thing, I'm forced by family commitments to down tools and go. (Male senior manager at Achill higher education institution)

The secondary nature of this caring enabled him to adapt his care responsibilities to came into work 'for a couple of hours every weekend' if he needed to; he was able to do this as his wife was the primary carer. While some men with children did make time accommodations to ensure their availability as secondary carers, they did not 
organise their entire work lives around childcare in the same way as female senior managers with children. All the women with dependent children who held senior management posts saw themselves as primary carers. Balancing the 'double burden' of senior management and caring work caused enormous tensions for these women (Hochschild 1997).

I didn't find that very easy and I didn't feel comfortable asking for any sort of accommodation to be made for it and indeed I didn't ask for accommodation to be made for it. But there would have been times when it would have been nice to manage things like my son being ill or this kind of stuff because he was quite young. (Female senior post holder at Rathlin higher education institution)

While none of the men interviewed spoke about having care dilemmas in relation to taking up their posts, a number of the women did. This was not just an issue for those with younger children. One senior manager who had moved home to take up her new post spoke about the difficulties that posed for her due to having teenage children living in another city: 'I came here but with great difficulty in so far as I was very concerned about my children, my daughters and in fact I commuted...for most of the first year' (Female senior manager at Valentia higher education institution). Care problems were time problems for women and time spent commuting exacerbated these time dilemmas. It lengthened the day and made meetings or work at night very difficult.

\section{Unbounded Work and the Long Hours Culture in Higher Education}

Both women and men regarded being a senior manager as immensely time consuming, not just in terms of the working day, but also in terms of the time invested outside of working hours (Warren 2003). A number of issues seemed to be crucial in 
determining this, including the increasing administrative demands that arose from new initiatives and legislation, the growth of an audit culture in education, and demands of fund-raising and strategic planning for the institution (Bottery 2000, Thrupp and Willmott 2003, Deem 2003). However, there were significant differences both between sectors of education and between women and men. Senior posts at higher education level were regarded as immensely time-consuming:

And to be quite honest, I mean, since I came into the post I'd say on average I work an 85 hour week, between 75 and 85 hours a week...You do work phenomenal hours and you are probably hearing this as well from school principals. That is another issue for women who still have caring responsibilities. I mean I don't, ...my children are grown up, I have nobody in [name of local city/town]. (Female assessor at Inismeain higher education institution)

The institutionalised legitimacy of the long-hours culture in higher education (as opposed to primary or second level, Lynch et al. 2006) was reflected in the responses of assessors for higher education positions regarding the level of commitment required to do the job.

I suppose what would be common at the top levels of these organisations is the buck does stop with you, issues do go to your desk all the time, it isn't 9 to 5 . That is the reality. You can try to control for that, you can do your best and people do, not to be dominated by it but there is a reality and probably it is most acute in the early years of the jobs when people make the transition and they don't have the comfort blanket of familiarity. (Male assessor at Saltees higher education institution)

The assessor at Saltees described senior appointments as entering a new way of working, almost a new way of life. It was not just about having a job. It was about taking responsibility and carrying that responsibility outside of working hours. It was not a time-bounded job: 'it is very difficult because at that level...the reality is the buck stops with you...you actually are taking on a whole range of responsibilities and commitments rather than a schedule of time'. 
This presumption of career dedication is allied with social relations of research production that assume academics have 'time, personally controlled time and carefree time to think, to write and re-write...[that they have the].. freedom from necessity to be an academic' (Lynch et al. 2007:2). Those who have this freedom tend to be those who do not have care responsibilities or can delegate these to others; they are care commanders. Only care commanders could live a life where there was no boundary between paid work and personal life.

I think it is not bad, I mean in the depths of winter when we are working 12 hours days and nights I can become an incredibly dull person to be around... work in a management post takes up a lot of time, even when you are on your vacation every couple of days you have just got to turn on the phone and people here expect that you will...And that is what they pay you for...the long hours work can overtake. (Female senior post holder at Saltees higher education institution)

While the belief that work time for senior managers was without boundaries was quite pervasive in higher education, there was also some ambivalence, a sense of resignation combined with a sense of frustration.

We have all this talk about work/life balance...most of us I'd say at the level I am at, it is just work, there is nothing else in our lives. That is an awful thing to say but there really is very little else if you want to really keep everything going. That is a big question as well for the university sector and the education sector generally. And that is why...all my colleagues...they see my light on at 7.00 in the morning and at 9:30 at night and they are saying 'why would I go there, why would I apply for that kind of a job?' (Female assessor at Inismeain higher education institution)

One high level senior manager`, with extensive experience as an assessor for senior posts in higher education and related sectors, believed Irish society was still maledominated and that a key problem arising from this was the lack of recognition of childcare and its demands. 
In my optimistic days I think it is changing slightly, not hugely I think it is still very much a male-dominated society and our perceptions and expectations around the whole childcare issues would still be very much middle ages (laughs). We have moved a little bit but not huge amounts. (Female assessor at Tory higher education institution)

A number of those interviewed felt that women were not even in the running to get interim senior posts (such as professorships), as they were not working at research productivity rates that would enable them to apply. There was a tendency to see this as a woman's choice, although one senior manager recognised that what needed to change was the work environment, not women.

I think also an awful lot of women are simply determining that their work/life balance and particularly their child-rearing possibilities would be absolutely constrained by being appointed to a more senior post. Also in universities for women faculty members, the fact that most promotion now prioritises research means that it is very difficult for them at a particular stage in their career, it is very difficult for women to be able to devote the amount of time that seems to be necessitated by producing research and publications...I really think that society needs to remodel how it looks at work. (Female senior manager at Valentia higher education institution).

Because work organisations do not take cognisance of the gendered division of care work at home (they do not have an integrated approach to assessment that takes account of staff's constraints in achieving goals as well as their opportunities, Rapoport 2002, Bailyn 2003), many women believe they will be seen to fall short in commitment and experience when seeking top-level posts. They often do not enter the competition because they know that legally permissible discriminations made at this level will disadvantage them (Bailey 2003, Knights and Richards 2003, Probert 2003).

\section{Conclusion: Care-Less Managers and the Care Ceiling}

The findings from the study of top-level appointments in higher education in Ireland 
suggest that there is a 'care' ceiling derived from women's caring work in the home, built from the strong moral imperative on women to be primary carers, an imperative that does not apply equally to men. Women carry that care ceiling into work, in a way which men - even those with young children do not, where it stays in place firmly fixed over their heads, reinforced at the base with concrete floors and walls of gendered 'care-free' expectations as to who is the ideal senior manager.

The growth of neo-liberal policies has exacerbated the impact of the care ceiling, especially at senior managerial level where the ideal worker is defined as being capable of working without time limits and without primary care responsibilities (Lynch 2007, Lynch et al. 2009). The impact of new managerialism is most evident in the higher education sector ${ }^{6}$ where the new capitalist academy (Slaughter and Leslie 2001) imposes expectations of performativity that only a care-less worker can fully satisfy (Moreau, et al. 2007). As women are significantly less likely to be care-free than men, regardless of their age or status, their capabilities for satisfying performativity demands are lesser within the new managerial regime (Bailyn 2003, Probert 2005).

This research demonstrates that senior managerial posts in higher education were defined as care-free zones. Senior male managers were care commanders, in that they assumed that women would do the primary caring in their lives; they could rely on the operation of the moral imperative on women to care (O'Brien 2007) to renege on primary care work. Senior women could not make the assumption that they were care commanders (although some were) as they were defined by their gender as care's foot soldiers. This invisible cost of balancing care and paid work responsibilities was 
evident in the older profile of senior managers, and in the case of women, the decision to have, or not to have, children.

The challenges faced by women in entering senior management are exacerbated by the lack of attention given to issues of care and interdependency in the public policy sphere; issues of care and interdependency are confined to the sub-altern in political terms (Fraser and Gordon 1997). They have been largely inadmissible subjects in public discourse. This invisibility of care work in the public sphere enables men to deny or remain sceptical about gender inequality.

The rules of participation for senior management posts are written largely by and for ‘care-less' people those who are not primary carers, or who can command others to do their care work. As Acker and Dillabough (2007:313) contend, the 'gender binary (e.g. motherhood versus male oriented success cultures) and its normative dimensions thus remains at the centre of many women's dilemmas putting brakes on any toooptimistic notions of agency inevitably accompanying social change'. Having equal opportunities policies, work-life balance programmes and campaigns to encourage women to see promotion will have little substantive impact on women's chances of leading universities and higher education colleges when the jobs are increasingly defined as precluding those who have care-full lives outside of work.

Note: The authors gratefully acknowledge the support of the Gender Equality Unit of the Department of Education and Science for this research.

\section{References:}


Acker, S. (1995) Carry on caring: the work of women teachers, British Journal of Sociology of Education 16(1), 21-36.

Acker, S. and J. Dillabough (2007) Women 'learning to labour' in the 'male emporium': exploring gendered work in teacher education, Gender and Education, 19(3), 297-316.

Allen, K. (2007) The corporate takeover of Ireland (Irish Academic Press, Dublin).

Angus, L. (2004) Globalization and educational change: bringing about the reshaping and re-norming of practice, Journal of Education Policy, 19(1), 23-41.

Apple, M. (2001) Educating the 'right' way (New York, Routledge Falmer).

Badgett, M. and N. Folbre (1999) Assigning care: gender norms and economic outcomes, International Labour Review, 138(3), 311-326.

Barry, J., Berg, E. and Chandler, J. (2003) Managing intellectual labour in Sweden and England, Cross-Cultural Management, 10(3), 3-22.

Barry, U. (Ed.) (2008) Where are we now? New Feminist Perspectives on Women in Contemporary Ireland (Dublin, TASC New Island Press).

Beck, U. and E. Beck-Gernsheim (2002) Individualization: Institutionalized individualism and its social and political consequences (London, Sage)

Bottery, M. (2000) Education, policy, ethics (London, Continuum).

Bailyn, L. (2003) Academic careers and gender equity: lessons learned from MIT, Gender Work \& Organization, 10(2) 137-153.

Blackmore, J. (1999) Troubling women: feminism, leadership and educational change (Buckingham, Open University Press).

Blackmore, J. (2002) Globalisation and the restructuring of higher education for new knowledge economies Higher Education Quarterly, 56(4) 419-441.

Blackmore, J. and Sachs, J (2000) Paradoxes of leadership and management in higher education in times of change, International Journal of Leadership in Education, 3(1) $1-16$.

Bok, D. (2003) Universities in the marketplace (Princeton, Princeton University Press).

Bonal, X. (2003) The neoliberal educational agenda and the legitimation crisis: old and new state strategies, British Journal of Sociology of Education 24(2), 159-175.

Bottery, M. (2000) Education, policy and ethics (London, Continuum). 
Brooking, K. Collins, G. Court, M. and J. O'Neill (2003) Getting below the surface of the principal recruitment 'crisis' in New Zealand primary schools, Australian Journal of Education 47(2), 146-159.

Connell, R.W. (2000) The men and the boys (Sydney, Allen and Unwin).

Coser, L. (1974) Greedy institutions (New York, The Free Press).

Currie, J. Harris, P. and Thiele, B. (2000) Sacrifices in greedy universities: are they gendered? Gender and Education 12(3), 269-291.

Daly, M. (2001) Care work: the quest for security (Geneva, International Labour Organization).

Davies, B. Gottsche, M. and P. Bansel (2006) The rise and fall of the neoliberal university, European Journal of Education, 41(2), 305-319.

Davies-Netzley, S. (1998) Women above the glass ceiling: perceptions on corporate mobility and strategies for success, Gender and Society, 12(3), 339-355.

Deem, R. and J. Ozga (2000) Transforming post-compulsory education? femocrats at work in the academy, Women's Studies International Forum, 23(2), 153-166.

Deem, R. (2003) Gender, organizational cultures and the practices of manager academics in UK universities, Gender Work and Organization, 10 (2), 239-259.

Ducklin, A. and J. Ozga (2007) Gender and management in further education in Scotland: an agenda for research, Gender and Education, 19 (5), 627-646.

Fineman, M. A. (2004) The autonomy myth: a theory of dependency (New York, New Press).

Folbre, N. and M. Bittman (2004) Family time: the social organization of care (London, Routledge).

Franzway, S. (2003) Women working in a greedy institution: commitment and emotional labour in the union movement, Gender, Work and Organization, 7(4) 258268.

Fraser, N. and Gordon, L. (1997) A genealogy of 'dependency'. In Fraser N. (ed) Justice interruptus: critical reflections on the 'postsocialist' condition (New York, Routledge), 121- 49

Gewirtz, S. Ball, S. and R. Bowe (1995) Markets, choice and equity in education (Buckingham, Open University Press).

Giroux, H. (2002) Neoliberalism, corporate culture, and the promise of higher education: the university as a democratic public sphere, Harvard Educational Review, 72(4), 1-31. 
Gronn, P. and Rawlings-Sanaei, F. (2003) Principal recruitment in a climate of leadership disengagement, Australian Journal of Education, 47(2), 172-185.

Grummell, B. Devine, D. and K. Lynch (2009) Appointing senior managers in education: homosociability, local logics and authenticity in the selection process, Educational Management Administration and Leadership, (forthcoming).

Harkavy, I. (2005) 'The role of the universities in advancing citizenship and social justice in the $21^{\text {st }}$ Century', Paper delivered to the Citizenship Education and Social Justice Conference, Queen's University Belfast, May 25 ${ }^{\text {th }}$.

Harvey,D.(2005) A brief history of neo-liberalism (Oxford, Oxford University Press).

Hearn, J. (1999) Men managers and management; the case of higher education. In S. Whitehead and R. Moodley (eds.) Transforming Managers: Gendering Change in the Public Sector (London, UCL Press), 36-52.

Hensel, N. (1991) Realizing gender equality in higher education: the need to integrate work/family issues, ASHE-ERIC Higher Education Report (Washington, ASHEERIC Higher Education Reports).

Hewlett, S.A. (2002) Executive women and the myth of having it all, Harvard Business Review, April, 66-73.

Hochschild, A. (1989) The second shift: working parents and the revolution at home (Harmondsworth, Penguin).

Irish Times 2006 Inspection reports prove a stumbling block, $20^{\text {th }}$ April, 6.

Kittay, E. F. (1999) Love's labor (New York, Routledge)

Knights, D. and W. Richards (2003) Sex discrimination in UK academia, Gender Work and Organization, 10(2), 213-238.

Lafferty, G. and J. Fleming (2000) The restructuring of academic work in Australia: power, management and gender, British Journal of Sociology of Education, 21(2), 257-267.

Lauder, H. and D. Hughes (1999) Trading in futures: why markets in education don't work (Buckingham, Open University).

Lynch, K. (2006) Neo-liberalism and marketisation: the implications for higher education, European Educational Research Journal, 5(1), 1-17.

Lynch, K. (2007) Love labour as a distinct and non-commodifiable form of care labour Sociological Review, Vol. 54, No. 3: 550-570.

Lynch, K., Baker, J. and Lyons, M. (2009) Affective equality: who cares? (London, Palgrave). 
Lynch, K. and Lyons, M. (2008) The gendered order of caring. In U.Barry (ed) Where are we now? new feminist perspectives on women in contemporary Ireland (Dublin, TASC New Island Press).

Lynch, K. Lyons, M. and S. Cantillon (2007) Breaking silence: educating citizens for love, care and solidarity, International Studies in Sociology of Education, 17(1\&2), 119.

Lynch, K. and Moran, M. (2006) Markets, schools and the convertibility of economic capital: the complex dynamics of class choice, British Journal of Sociology of Education, 27(2), 221-235.

Lynch, K. Grummell, B. Devine, D. and M. Lyons (2006) Senior appointments in education: a study of management culture and its gender implications (Dublin, Gender Equality Unit, Department of Education and Science).

Lyons, M. Lynch, K. Close, S. Sheerin, E. and P. Bland (2003) Inside Classrooms: The Teaching and Learning of Mathematics in Social Context (Dublin, Institute of Public Administration).

McGauran, A-M (2004) Plus ca change...? gender mainstreaming of the Irish National Development Plan (Dublin, TCD Policy Institute)

Masschelein, J. and Simons, M. (2002) An adequate education in a globalised world? a note on immunisation against being-together, Journal of Philosophy of Education, 36(4), 589-608

Moreau, M. Osgood, J. and A. Halsall (2007) Making sense of the glass ceiling in schools: an exploration of women teachers' discourses, Gender and Education, 19(2), 237-253.

Morley, L. (1999) Organising feminisms: the micropolitics of the academy (Basingstoke, Macmillan).

Nodding, N. (2003) Caring: a feminine approach to ethics and moral education (Berkeley, University of California Press).

Nussbaum, M. (2001) Upheavals of thought: the intelligence of emotions (Cambridge: Cambridge University Press)

O'Brien, M. (2007) Mothers' emotional care work in education and its moral imperative, Gender and Education 19(2), 159-177.

O'Brien, M. (2008) Gendered capital: emotional capital and mothers' care work in education, British Journal of Sociology of Education 29(2), 137-148

O'Connor, P. (2007a) The elephant in the corner: gender and policies related to higher education, paper presented at Conference on Women in Higher Education, Queens University Belfast, April $19^{\text {th }}-20^{\text {th }}$ 
O'Connor, M. (2007b) Sé sí: gender in Irish education (Dublin, Department of Education and Science).

OECD (2004) National policies for education: review of higher education in Ireland EDU/EC 14, (Paris, OECD).

Ozga, J. and Deem, R. (2000) Carrying the burdens of transformation: the experience of women managers in the UK, higher and further education, Discourse 21(2), 141153.

Pettinger, L., Parry, J., Taylor, R. and Gluckmann, M. (eds) (2006) A new sociology of work? (Oxford, Basil Blackwell).

Probert, B. (2005) 'I just couldn't fit it in': gender and unequal outcomes in academic careers, Gender Work and Organisation, 12(1), 50-72.

Ramsay, K. and Leterby, G. (2006) The experience of non-mothers in the gendered university, Gender, Work and Organization 13(1), 25-44.

Rapoport, R., Bailyn, L., Fletcher, J.K. and Pruitt, B.H. (2002) Beyond work-family balance: advancing gender equity and workplace performance (San Francisco, Jossey-Bass).

Reay, D. and H. Lucey (2003). The limits of 'choice': children and inner city schooling, Sociology, 37(1), 121-142.

Reay, D. David, M. and S. Ball (2005) Degrees of choice: social class, race and gender in higher education (Stoke-on-Trent, Trenham Books).

Rutherford, J. (2005) Cultural studies in the corporate university, Cultural Studies 19(3), 297-317.

Sevenhuijsen, S. (1998) Citizenship and the ethics of care: feminist considerations on justice, morality and politics (London, Routledge).

Slaughter, S. and Leslie, L.L. (2001) Expanding and elaborating the concept of academic capitalism, Organization 8(2), 154-161.

Stanley, L. (1997) Knowing feminisms: on academic borders, territories and tribes (London, Sage).

Stevenson, M. (1999) Flexible education and the discipline of the market, International Journal of Qualitative Studies in Education, 12(3), 311-323.

Sugrue, C. (2004) Curriculum and ideology: Irish experiences, international perspectives (Dublin, Liffey Press).

Taylor, J., (2001) The impact of performance indicators on the work of university academics: evidence from Australian universities, Higher Education Quarterly, 55(1), 42-61. 
Thrupp, M. and R. Wilmott (2003) Educational management in managerialist times: beyond the textual apologists (Buckingham, Open University).

Tronto, J. C. (1993) Moral boundaries: a political argument for an ethic of care (New York, Routledge).

Tronto, J.C. (2001) Who cares? public and private caring and rethinking Citizenship. In N.J. Hirschmann, and U. Liebert (eds) Women and welfare: theory and practice in the United States and Europe (Brunswick, Rutgers University Press), 65-83.

Warren, T. (2003) Class and gender-based working time? time poverty and the division of domestic labour, Sociology, 37(4), 733-752.

Wilkinson, J. and Blackmore, J. (2008) Re-presenting women and leadership: a methodological journey, International Journal of Qualitative Studies in Education, 21 (2) 123-136.

Williams, F. (2004) Rethinking families (London, Calouste Gulbenkian Foundation).

\footnotetext{
${ }^{1}$ The study is part of a larger study of 27 case studies of senior appointments at primary, second-level and third-level education in Ireland. It involved analysing the entire appointments process from advertisement to short listing, interviews, and appointment. We undertook 50 interviews with top-level appointees and their assessors, and analysed relevant documentary material relating to their appointments.

2 The higher education sector in Ireland consists of seven universities, 14 institutes of technology and other recognised colleges as well as a range of private colleges. The further education sector consists of a range of public and private colleges giving Further Education and Training Awards Council (FETAC) courses. A range of statutory agencies advise and develop educational strategies for the Department of Education and Science. Casestudies were completed with a recently appointed senior manager and one or more assessors from their selection panels from a range of these institutions.
}

3 Statistics on educational personnel in Irish higher education reveal sharp gender inequalities, especially at more senior levels. While $10 \%$ of those holding full professorships in Ireland were women in 2004 and 15\% were associate professors (compared with $4 \%$ and $6 \%$ respectively ten years previously in 1994) the proportion of women at the very lowest end of the academic hierarchy, has also increased: $47 \%$ of those who were assistant lecturers or other teaching staff in 2004 were women compared with 39\% in 1994 while $43 \%$ of those who were college lecturers (the level just below the career grade of senior lecturer) were women in 2004 compared with 28\% in 1994 (O’Connor 2007a). The proportion of men increases with the seniority of the academic and management position, most noticeably in the university and civil service sectors (Lynch et al. 2006, O’Connor 2007b).

${ }^{4}$ The names of the institutions are replaced with pseudonyms from the names of Irish Islands to preserve confidentiality.

${ }^{5}$ Regardless of partners however, women spoke about feelings of isolation in a male-dominated management culture. One of the assessors, who also held a senior post, spoke about how:

'Once you come up into the management level it is a very tough scene...that is one of the changes in higher education that once you go into management you are the enemy...I would have many, many experiences of men taking each other on and it being a fight to the end...I don't think intuitively, instinctively women have the same fighting instinct' (Female Assessor at Inismeain higher education institution)

Another senior manager described her first experience of her senior post as follows:

'You were joining a man's club where at coffee they talked about sport and told off-colour jokes... you got the impression that you had changed the dynamic of their world a little..you were disturbing the club' (Female Senior Manager, at Saltees higher education institution) 
${ }^{6}$ It must be noted that the long hours work culture was also expanding into primary and second level but it was limited by a variety of factors, include the feminisation of the teaching profession and trade union activity indicating the complexity of organisational cultures in education (Lynch et al. 2006). 